\title{
Agronomic performance for biodiesel production potential of Brassica carinata A. Braun in Mediterranean marginal areas
}

\author{
Francesco Montemurro, ${ }^{1}$ Mariangela Diacono, ${ }^{2}$ Marcello Scarcella, ${ }^{2}$ Laura D'Andrea, ${ }^{2}$ \\ Francesca Boari, ${ }^{3}$ Angelo Santino, ${ }^{4}$ Marcello Mastrorilli ${ }^{2}$
}

\begin{abstract}
${ }^{1}$ Research Unit for Agriculture in Dry Environments, Council for Agricultural Research and Economics, Experimental Farm of Metaponto (MT); ${ }^{2}$ Research Unit for Agriculture in Dry Environments, Council for Agricultural Research and Economics, Bari; ${ }^{3}$ Institute of Sciences of Food Production, National Research Council, Bari; ${ }^{4}$ Institute of Sciences of Food Production, National Research Council, Lecce, Italy
\end{abstract}

\begin{abstract}
Brassicaceae are promising oil feedstock for cultivation in centralsouthern Italy. Therefore, a two-year investigation on Brassica carinata A. Braun (cv. CT 204) was carried out in three sites of Apulia region [Site 1, Alberobello - Murgia foreland; Site 2, Troia (Foggia) - Daunian sub-Apennines; Site 3, Monteroni (Lecce) - Area of Salento], and in one site of Basilicata region (Site 4, Hill of Matera). The aim was to identify site-specific management practices [by comparing minimum $v s$ conventional tillage, low sowing density $v s$ high sowing density; different levels of nitrogen (N) supply and organic fertilisers] in the four different marginal areas, to achieve optimum yield performance for biodiesel prospective production. The crop showed a good adaptability in the study sites, and the highest $\mathrm{N}$ level positively influenced the yield performance in Sites 1, 2 and 3. Moreover, the reduction of mechanical operations (minimum tillage) did not negatively influence crop production and seed oil content. The highest density of sowing
\end{abstract}

\footnotetext{
Correspondence: Mariangela Diacono, Research Unit for Agriculture in Dry Environments, Council for Agricultural Research and Economics (CREA), via Celso Ulpiani 5, 70125 Bari, Italy.

Tel.: +39.080 .5475052 - Fax: +39.080 .5475023 .

E-mail: mariangela.diacono@crea.gov.it

Key words: Bioenergy crops; conservation tillage; Ethiopian mustard; fertilisation; site-specific management; sowing density.

Funding: the work has been supported by the Italian Ministry of Agriculture and Forestry Policies and coordinated by CREA (research project: Bioenergy for Sustainable Development in Semi-Marginal and Marginal Areas of Southern Italy - SOBIMA).

Received for publication: 4 May 2015.

Revision received: 13 November 2015.

Accepted for publication: 16 November 2015.

(C) Copyright F. Montemurro et al., 2016

Licensee PAGEPress, Italy

Italian Journal of Agronomy 2016; 11:684

doi:10.4081/ija.2016.684

This article is distributed under the terms of the Creative Commons Attribution Noncommercial License (by-nc 4.0) which permits any noncommercial use, distribution, and reproduction in any medium, provided the original author(s) and source are credited.
}

tested determined the best crop performance in Site 3, particularly showing the maximum seed oil content with the lowest $\mathrm{N}$ supply. Finally, in Site 4 the compost mixed with mineral $\mathrm{N}$ fertiliser as well as the sewage sludge from urban wastewater determined productive results comparable to those obtained with mineral fertiliser, evidencing that organic fertilisers could (partially or completely) substitute the mineral one for this crop in the study site. On the whole, seed yield and oil content showed a potential for biodiesel production of Brassica carinata cultivated with site-specific agronomic techniques in four different marginal areas of Southern Italy, suggesting it can be likely achieved the crop environmental adaptation.

\section{Introduction}

The European Directive has established that 20\% of energy consumption should be represented by renewable energy sources by 2020 in each European member state (Fischer et al., 2010). Potential bioenergy feedstocks include materials such as herbaceous crops and agricultural/forest residues, and estimates of land potentials for feedstock production range from 20 to 60 Mha for the EU25 by 2020 or 2030 (EEA, 2007). However, despite bioenergy crops may compete for land and resources with food crops, some species could be grown in marginal lands with beneficial agro-environmental effects (Zegada-Lizarazu et $a l ., 2010$ ). Therefore, choosing the appropriate species and management approaches should be site-specific.

Cosentino et al. (2008) reported that from the 1990s onward attention has been particularly focused on Brassicaceae for biodiesel production. This is the case of Ethiopian mustard (Brassica carinata A. Braun), a native plant of the Ethiopian highlands with high erucic and linolenic acids in the extracted oil (Cardone et al., 2003). The crop has shown better adaptability and productivity than B. napus under unfavourable environmental conditions and low cropping systems, for its flowering earliness, resistance to lodging, large seed size and good shattering resistance, as well as both drought and heat tolerance (Pan et al. 2012; Stamigna et al., 2012).

According to Cardone et al. (2003), B. carinata is a promising oil feedstock for cultivation particularly in central-southern Italy. Moreover, as it was demonstrated in recent studies, residues deriving from biodiesel chain based on $B$. carinata crop can have interesting energy content, and their exploitation can improve the energy balance of biodiesel production (Del Gatto et al., 2015; Duca et al., 2015).

However, there is a need to identify the key management practices, such as tillage, seeding rate and nitrogen (N) supply, for achieving optimum seed yield and quality (Pan et al., 2012). To the best of our 
knowledge, there are no scientific evidences about the effectiveness of B. carinata adaptation particularly in marginal areas of southern Italy, for biofuel potential production, as a sustainable alternative to fossil fuel. Therefore, this two-year research was aimed to identify the best management practices to be used for crop cultivation, assessing the productive performance of $B$. carinata in four different marginal areas under Mediterranean conditions. The selected study sites had the following different causes of marginality and semi-marginality: i) soils with medium-high slope, which could determine crop yield reduction; ii) absence of irrigation water; and iii) climate variability. Therefore, the farming techniques tested on $B$. carinata in the four sites were sitespecific and oriented to minimise inputs and maximise yields.

\section{Materials and methods}

\section{Study sites}

A two-year rotation of B. carinata (cv. CT 204) with different cereal crops was carried out in Southern Italy. Field experiments were conducted in three sites of Apulia region [Site 1, Alberobello - Murgia foreland; Site 2, Troia (Foggia) - Daunian sub-Apennines; Site 3, Monteroni (Lecce) - Area of Salento] and in one site of Basilicata region (Site 4, Hill of Matera). The four experimental trials were conducted during 2010-2011 and 2011-2012 cropping seasons. The climate of the experimental sites is accentuated thermo-Mediterranean, as classified by the United Nations Educational Scientific and Cultural Organization-Food and Agriculture Organization (UNESCO-FA0, 1963), with winter temperatures that can fall below $0^{\circ} \mathrm{C}$ and summer temperatures that can rise above $40^{\circ} \mathrm{C}$, and rainfall unevenly distributed during the year and mainly concentrated in winter months. The main characteristics of the study sites and their climatic characterisation during the field trials are reported hereafter.

\section{Site 1, Alberobello - Murgia foreland}

At Site 1, the field trial was carried out by the Research Unit for Agriculture in Dry Environments, Council for Agricultural Research and Economics (SCA-CREA) of Bari in a hilly area, located at Alberobello (BA) $\left(40^{\circ} 45^{\prime} 35^{\prime \prime} \mathrm{N}, 17^{\circ} 12^{\prime} 21^{\prime \prime} \mathrm{E}, 428 \mathrm{~m}\right.$ a.s.l.), which is characterised by a soil layer of $15-40 \mathrm{~cm}$ depth, resting on cracked and often emerging rocks. According to the Soil Taxonomy of the United States Department of Agriculture (USDA), the soil is a Typical Palexeralf clayey-skeletal, characterised by $35 \%$ rock fragment ( $>2$ $\mathrm{mm}$ ) and 20\% slope (Soil Survey Staff, 1999).

During the first crop cycle, the total rainfall was $815 \mathrm{~mm}$ (data not shown), which was considerably higher than the long-term (30-year period) value $(519 \mathrm{~mm})$, and the wettest months were October, March and May. Monthly values of mean temperatures showed minimum value in December $2010\left(-2.4^{\circ} \mathrm{C}\right)$, and maximum $\left(32.2^{\circ} \mathrm{C}\right)$ value in June. During 2011-2012, the total rainfall was slightly lower (779 mm; data not shown) than in the first one, and the wettest months were November and February. Minimum temperature values were detected both in mid-January $\left(-1.02^{\circ} \mathrm{C}\right)$ and February $\left(-1.16^{\circ} \mathrm{C}\right)$ and the maximum temperature $\left(35.3^{\circ} \mathrm{C}\right)$ was observed in June.

\section{Site 2, Troia (Foggia) - Daunian sub-Apennines}

At Site 2, the field trial was carried out by the Institute of Sciences of Food Production, National Research Council (ISPA-CNR) of Bari at Troia (Foggia) (41 $20^{\prime} 21^{\prime \prime} \mathrm{N}, 15^{\circ} 24^{\prime} 00^{\prime \prime} \mathrm{E}, 300 \mathrm{~m}$ a.s.l.), in a hilly area of the Daunian sub-Apennines with $20-30 \%$ slope, on a soil with a clayloam texture and rich in skeleton.

During the first crop cycle, the total rainfall was $595 \mathrm{~mm}$ (data not shown), being considerably higher than in the long-term period (383 $\mathrm{mm}$ ). The wettest months were October, November and March. The temperature from mid-December to mid-March was equal to or below $0^{\circ} \mathrm{C}$, with a minimum value of $-7.8^{\circ} \mathrm{C}$ in December. The highest temperature $\left(35.9^{\circ} \mathrm{C}\right)$ was observed in June. In $2011-2012$, the total rainfall (336 mm) was notably lower both than in the first year and in the longterm period, and the wettest months were February and April. The January-February period was characterised by very low temperatures and snowfall that produced a snowpack of $20-50 \mathrm{~cm}$, covering the crop for about 10 days. The minimum temperature was below $0^{\circ} \mathrm{C}$ in 22 days, with a minimum of $-7.6^{\circ} \mathrm{C}$ in February. The highest temperature $\left(41.8^{\circ} \mathrm{C}\right)$ was observed, again, in June.

\section{Site 3, Monteroni (Lecce) - Area of Salento}

At Site 3 , the field trial was carried out by the Research Unit for the Identification and Study of High Value Crops in Dry Environments, Council for Agricultural Research and Economics (CAR-CREA) in the experimental farm of S. Anna at Monteroni (Lecce) $\left(40^{\circ} 33^{\prime} 20^{\prime \prime} \mathrm{N}, 18^{\circ}\right.$ 10 ' 27 " E, $35 \mathrm{~m}$ a.s.l.), on a deep sand loamy soil. During the first crop cycle, the total rainfall was $302 \mathrm{~mm}$ (data not shown), which was slightly higher than the long-term value $(293 \mathrm{~mm})$, and the wettest months were January and March. The lowest mean temperature was observed in January $\left(8.1^{\circ} \mathrm{C}\right)$ and the highest one in July $\left(25.9^{\circ} \mathrm{C}\right)$. In the second crop cycle, the total rainfall was $390 \mathrm{~mm}$ (data not shown), which was higher than the long-term value, with February and July as wettest months. The lowest temperature was observed in January $\left(7^{\circ} \mathrm{C}\right)$ and the maximum temperature value occurred in July $\left(28.1^{\circ} \mathrm{C}\right)$.

\section{Site 4, Hill of Matera}

At Site 4, the field trial was carried out by SCA-CREA (Experimental Farm of Metaponto) at Matera ( $41^{\circ} 27^{\prime} \mathrm{N}, 3^{\circ} 04^{\prime} \mathrm{E}, 250 \mathrm{~m}$ a.s.l.), on a cereal farm typical of the study area. According to Soil Taxonomy USDA the soil of the field is a Vertisol of alluvial origin, classified as Typic Chromoxerert, Fine, Mesic (Soil Survey Staff, 1999). The experimental field is located in a marginal area, characterised by soils with high degree of slope and rainfall unevenly distributed during the year. During the first crop cycle, the total rainfall was $509 \mathrm{~mm}$ (data not shown), and the wettest months were November and March. Monthly values of mean temperatures showed minimum value in February 2011 $\left(2.1^{\circ} \mathrm{C}\right)$, whereas the maximum temperature $\left(31.4^{\circ} \mathrm{C}\right)$ was observed in June. In the second crop cycle the total rainfall $(350 \mathrm{~mm})$ was notably lower than in the long-term period $(619 \mathrm{~mm})$, and the wettest months were February and April. Monthly values of mean temperatures showed minimum value in January $2012\left(-0.1^{\circ} \mathrm{C}\right)$, whereas the maximum temperature $\left(35.3^{\circ} \mathrm{C}\right)$ was observed in June.

\section{Experimental setup, treatments and measurements in each study site}

The main agronomic information regarding experimental design, experimental treatments and crop measurements are reported below, for the four study sites. In each site, the crop was harvested when the seed moisture content was about $9 \%$. At harvesting, samples of crop seeds were analysed for oil content with the European conventional methodology.

\section{Site 1, Alberobello - Murgia foreland}

In the autumn of 2010 (on soil left to set aside), minimum tillage was performed with two disk harrowings before sowing (at $10 \mathrm{~cm}$ soil depth, after rainfall, and at $5 \mathrm{~cm}$ ), whereas in the autumn of 2011 soil was tilled after oats harvesting. In pre-sowing, fertilisers were distributed at a rate of $100 \mathrm{~kg} \mathrm{ha}^{-1}$ both as $\mathrm{P}_{2} \mathrm{O}_{5}$ (triple superphosphate) and $\mathrm{K}_{2} \mathrm{O}$ (potassium sulphate). 
The crop was sown, in rows spaced $60 \mathrm{~cm}$, on $8^{\text {th }}$ October 2010 and $5^{\text {th }}$ October 2011. The experimental design was a randomised block with three replications and elementary plots of $75 \mathrm{~m}^{2}$. The following levels of $\mathrm{N}$ fertilisation were compared: i) unfertilised control (N0); ii) $50 \mathrm{~kg} \mathrm{~N}$ $\mathrm{ha}^{-1}$ (N50); and iii) $100 \mathrm{~kg} \mathrm{~N} \mathrm{ha}^{-1}$ (N100). Nitrogen fertiliser (ammonium sulphate) was applied at the beginning of the growth season, at the stage of $10^{\text {th }}-12^{\text {th }}$ leaf. The crop was harvested on $28^{\text {th }}$ June 2011 and $2^{\text {nd }}$ July 2012 and the following parameters were determined: seed yield $(\mathrm{t}$ ha $\left.^{-1}\right), 1000$ seed weight (g), number of siliques plant ${ }^{-1}$, number of seeds silique ${ }^{-1}$, plant height $(\mathrm{cm})$ and total dry biomass $\left(\mathrm{t} \mathrm{ha}^{-1}\right)$.

\section{Site 2, Troia (Foggia) - Daunian sub-Apennines}

In a split-plot experimental design with three replications and elementary plots of $100 \mathrm{~m}^{2}$, the following tillage systems (main plot factor) were compared: i) conventional tillage (CT) and ii) minimum tillage (MT). The CT treatment included mouldboard plowing (40 cm depth) in late August and disk harrowing both at $10 \mathrm{~cm}$, after rainfall, and at 5 $\mathrm{cm}$ before sowing to prepare seedbed. The MT treatment consisted of disk harrowing ( $5 \mathrm{~cm}$ depth) before sowing, simultaneously to the last CT tillage. In the sub-plots, three $\mathrm{N}$ (urea) levels were compared: i) 0 $\mathrm{kg} \mathrm{N} \mathrm{ha}^{-1}$ as control (N0), ii) $50 \mathrm{~kg} \mathrm{~N} \mathrm{ha}^{-1}$ (N50), and iii) $100 \mathrm{~kg} \mathrm{~N} \mathrm{ha}^{-1}$ (N100). The fertiliser was applied splitting the rate (in the N50 and N100 treatments) as $60 \%$ at mid-December and $40 \%$ at mid-January.

The crop was sown in rows spaced $15 \mathrm{~cm}$, on $20^{\text {th }}$ October 2010 and $21^{\text {st }}$ October 2011. A sampling area of $80 \mathrm{~m}^{2}$ was harvested on $28^{\text {th }}$ June 2011 and on $4^{\text {th }}$ July 2012, with a combine harvester, and the following parameters were determined: seed yield $\left(\mathrm{t} \mathrm{ha}^{-1}\right), 1000$ seed weight $(\mathrm{g})$, number of siliques plant $^{-1}$, number of seeds silique ${ }^{-1}$, plant height (cm) and total dry biomass $\left(\mathrm{t} \mathrm{ha}^{-1}\right)$.

\section{Site 3, Monteroni (Lecce) - Area of Salento}

In a split-plot experimental design with three replications and elementary plots of $20 \mathrm{~m}^{2}$, the following three levels of $\mathrm{N}$ fertilisation (ammonium sulphate 21\%) were compared as main plot factor: i) $0 \mathrm{~kg}$ $\mathrm{N} \mathrm{ha}^{-1}$ as a control (N0); ii) $60 \mathrm{~kg} \mathrm{~N} \mathrm{ha}^{-1}$ (N60); and iii) $120 \mathrm{~kg} \mathrm{~N}^{-1}$ (N120). Moreover, in the sub-plots, two sowing densities were tested: i) low density (L) with 50 plants $\mathrm{m}^{-2}$; and ii) high density (H) with 100 plants $\mathrm{m}^{-2}$. Minimum soil tillage was performed with disk harrowings (at 10 and $5 \mathrm{~cm}$ depth), simultaneously to a pre-sowing fertilisation with $120 \mathrm{~kg} \mathrm{ha}^{-1} \mathrm{P}_{2} \mathrm{O}_{5}$. The crop was sown on $4^{\text {th }}$ January 2011 and $7^{\text {th }}$ December 2011 (average seed weight: $5 \mathrm{~g} 1000$ seeds $^{-1}$ ), by using a mini seeder. The harvesting was done on $11^{\text {th }}$ July 2011 and on $1^{\text {sh }}$ August 2012, and the following parameters were determined: seed yield $\left(\mathrm{t} \mathrm{ha}{ }^{-1}\right), 1000$ seed weight $(\mathrm{g})$, number of siliques plant ${ }^{-1}$, number of seeds silique ${ }^{-1}$, and plant height $(\mathrm{cm})$.

\section{Site 4, Hill of Matera}

The experimental design was a split-plot with three replications and elementary plots of $9 \mathrm{~m}^{2}$. The following two methods of soil tillage (main plot factor) were compared: i) conventional tillage (CT), which was carried out with ripper at $50 \mathrm{~cm}$ of soil depth; and ii) minimum tillage (MT), with clod-smasher at $20 \mathrm{~cm}$ of soil depth. Furthermore, two disk harrowings to prepare seedbed were performed both in CT and MT plots. Different fertilising treatments were tested within each soil tillage treatment: i) mineral $\mathrm{N}$ fertiliser (urea $46 \% \mathrm{~N}$ ), at $100 \mathrm{~kg} \mathrm{~N} \mathrm{ha}^{-1}$ (N100); ii) organic fertilisation with compost [2\% N; Progeva srl, Laterza (TA), Italy], obtained from municipal solid wastes, at $100 \mathrm{~kg} \mathrm{~N}$ $\mathrm{ha}^{-1}$ (100COMP); iii) compost mixed with mineral $\mathrm{N}$ fertiliser (MIX) (i.e., $50 \mathrm{~kg} \mathrm{~N} \mathrm{ha}^{-1}$ as compost plus $50 \mathrm{~kg} \mathrm{~N} \mathrm{ha}^{-1}$ as mineral fertiliser); iv) sewage sludge from urban wastewater (SSW) at $100 \mathrm{~kg} \mathrm{~N} \mathrm{ha}^{-1}$. These treatments were supplied in early autumn, 1 month before sowing, and they were compared with an unfertilised control (N0). As regards compost, the total organic carbon content $\left(266 \mathrm{~g} \mathrm{~kg}^{-1}\right)$ exceed- ed the minimum value of $200 \mathrm{~g} \mathrm{~kg}^{-1}$ established by the Italian Legislative Decree no. 75/2010 (Italian Regulation, 2010). Moreover, the copper $(\mathrm{Cu})\left(125 \mathrm{mg} \mathrm{kg}^{-1}\right)$, zinc (Zn) $\left(269 \mathrm{mg} \mathrm{kg}^{-1}\right)$, nickel (Ni) $\left(6.15 \mathrm{mg} \mathrm{kg}^{-1}\right)$, and lead $(\mathrm{Pb})\left(33.8 \mathrm{mg} \mathrm{kg}^{-1}\right)$ values were all lower than the established limits (i.e., 230, 500, 100 and $140 \mathrm{mg} \mathrm{kg}^{-1}$, respectively). Similarly, the values of the heavy metals (i.e., $\mathrm{Cu} 280 \mathrm{mg} \mathrm{kg}^{-1}$; Zn 1074 $\mathrm{mg} \mathrm{kg}$; $\mathrm{Ni} 20.7 \mathrm{mg} \mathrm{kg}^{-1}$; $\mathrm{Pb} 79.3 \mathrm{mg} \mathrm{kg}^{-1}$ ), as main potentially toxic elements in the sewage sludge, were lower than the maximum permissible limits for land application (1750 mg kg-1; $4000 \mathrm{mg} \mathrm{kg}^{-1} ; 400 \mathrm{mg}$ $\mathrm{kg}^{-1} ; 1200 \mathrm{mg} \mathrm{kg}^{-1}$, for $\mathrm{Cu}, \mathrm{Zn}, \mathrm{Ni}, \mathrm{Pb}$, respectively) fixed by the Directive 86/278/EEC (European Commission, 1986). The crop was sown in mid-November and harvested in the second half of June in both trial years. At harvesting, the following parameters were determined: seed yield $\left(\mathrm{t} \mathrm{ha} \mathrm{h}^{-1}\right), 1000$ seed weight $(\mathrm{g})$, number of siliques plant $^{-1}$, number of seeds silique ${ }^{-1}$, plant height $(\mathrm{cm})$, total dry biomass $\left(\mathrm{t} \mathrm{ha}^{-1}\right)$.

\section{Statistical analysis}

Data were submitted to the analysis of variance, and the differences between means were further analysed with the Duncan's multiple range test $(\mathrm{P}<0.05)$. The statistical analysis was carried out by using the STAT software 2012, release 9.3 (SAS Institute Inc., Cary, NC, USA).

\section{Results}

\section{Site 1}

In 2010-2011, 1000 seeds weight, plant height and total biomass were lower than in the second one (Table 1). In the first cropping cycle the N100 treatment determined the highest mean value of crop yield, being higher by $29.2 \%$ and $56.6 \%$ than N50 and N0 treatments, respectively. By contrast, the total biomass after application of the highest dose of $\mathrm{N}$ was comparable to that in N0 treatment plots, whereas N50 determined the highest value, which was significantly higher by $23.5 \%$ than in N100. In the second crop cycle, N100 showed both the highest crop yield and biomass values. In particular, the yield in N100 was significantly higher by $28.8 \%$ and $55.3 \%$ than N50 and N0, respectively, and the total biomass was significantly higher by $20.2 \%$ and $37.1 \%$, respectively. In Figure 1 the seed oil content (\%), divided by year and $\mathrm{N}$ fertiliser dose, is reported. The N50 and N100 treatments determined

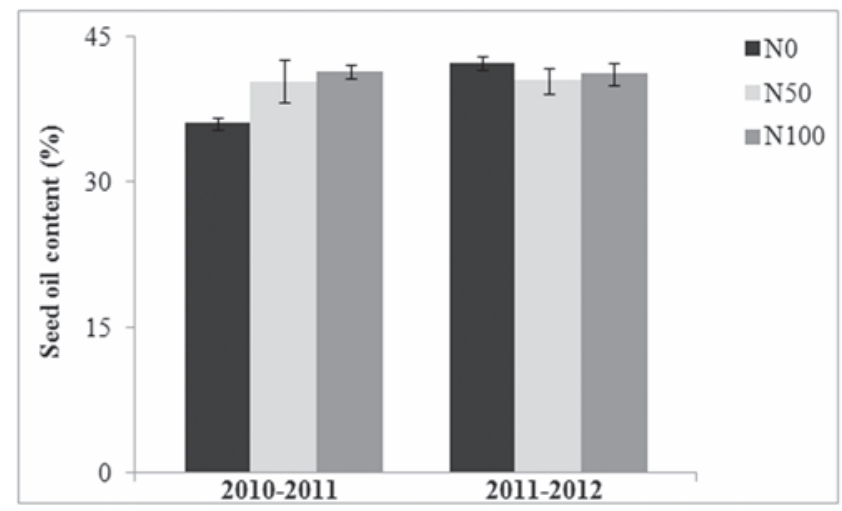

Figure 1 . Seed oil content (\%) in Site 1 divided by year and nitrogen $(\mathrm{N})$ fertiliser dose. Reported values are mean \pm standard deviation. 
comparable and significantly higher values than N0 in the first year, whereas in the second one there was an inverse trend even if the differences were observed in absolute value.

\section{Site 2}

The output of the analysis of variance revealed significant main effect of year for yield, 1000 seeds weight and siliques plant ${ }^{-1}$. Main effect of tillage strategy was found for almost all parameters except siliques plant ${ }^{-1}$ and seeds silique ${ }^{-1}$, whereas main effect of nitrogen level was found for all the parameters taken into consideration (Table 2). In addition, all the two-way interactions where not significant.

The N100 dose of fertiliser determined the highest values for all parameters, whereas the N50 determined intermediate values. In particular, crop yield was significantly higher in N100 by $84.6 \%$ and $33.3 \%$ than in $\mathrm{N} 0$ and $\mathrm{N} 50$, respectively.

In 2010-2011, no substantial differences were found for seed oil content among $\mathrm{N}$ fertiliser levels for each tillage strategy (Figure 2).
Moreover, no significant differences were found between CT and MT strategy. In 2011-2012, the highest oil content (38.1\%) in absolute terms was determined by N0 in CT, whereas in MT the lowest value was found for N50 (34.9\%). Again no significant differences were found between CT and MT strategies.

\section{Site 3}

The output of the analysis of variance revealed significant main effects of year except for 1000 seeds weight and seeds silique ${ }^{-1}$, and except for 1000 seeds weight, seeds silique ${ }^{-1}$ and plant height as for density effect. No interactions between treatments were found (Table 3). The highest yield was found in the second cropping cycle (being higher by $18.0 \%$ than in the first one), which also showed the highest silique plant ${ }^{-1}$. Among $\mathrm{N}$ levels, N120 determined yield significantly higher by $18.2 \%$ and $63.9 \%$ than $\mathrm{N} 60$ and $\mathrm{N} 0$ treatment, respectively, whereas it showed 1000 seeds weight comparable to N0 and significantly lower than in N60. The highest silique plant ${ }^{-1}$ and plant height values were found in

Table 1. Effects of year, and interactions with levels of $\mathrm{N}$ fertilisation, on crop performance at Site 1.

\begin{tabular}{|c|c|c|c|c|c|c|}
\hline & $\begin{array}{l}\text { Yield } \\
\left(\mathrm{t} \mathrm{ha}^{-1}\right)\end{array}$ & $\begin{array}{c}1000 \text { seeds weight } \\
\text { (g) }\end{array}$ & $\begin{array}{l}\text { Silique plant } \\
\text { (n) }\end{array}$ & $\begin{array}{l}\text { Seeds silique }{ }^{-1} \\
\text { (n) }\end{array}$ & $\begin{array}{l}\text { Plant height } \\
(\mathrm{cm})\end{array}$ & $\begin{array}{l}\text { Total biomass } \\
\qquad\left(\mathrm{t} \mathrm{ha}^{-1}\right)\end{array}$ \\
\hline \multicolumn{7}{|l|}{ Year } \\
\hline 2010-2011 & 1.42 & $5.2^{\mathrm{b}}$ & 96.0 & 12.3 & $113 b$ & $2.52^{\mathrm{b}}$ \\
\hline \multirow[t]{2}{*}{ 2011-2012 } & 1.40 & 6.1a & 96.3 & 11.2 & $129^{a}$ & $7.07^{a}$ \\
\hline & $\mathrm{ns}$ & $* *$ & $\mathrm{~ns}$ & ns & $*$ & $*$ \\
\hline \multicolumn{3}{|c|}{ Interactions (YxN) } & \multicolumn{2}{|c|}{$2010-2011$} & & \\
\hline \multicolumn{7}{|c|}{$\mathrm{N}$ level } \\
\hline N0 & $1.13^{\mathrm{c}}$ & 5.0 & 96.0 & 12.0 & 112 & $2.42^{\mathrm{b}}$ \\
\hline N50 & $1.37^{\mathrm{b}}$ & 5.6 & 79.1 & 11.8 & 108 & $2.84^{\mathrm{a}}$ \\
\hline N100 & $1.77^{\mathrm{a}}$ & 4.9 & 113 & 12.9 & 121 & $2.30^{\mathrm{b}}$ \\
\hline \multicolumn{3}{|c|}{ Interactions (YxN) } & \multicolumn{2}{|c|}{ 2011-2012 } & & \\
\hline \multicolumn{7}{|l|}{$\mathrm{N}$ level } \\
\hline N0 & $1.12^{\mathrm{c}}$ & 6.3 & 73.0 & 10.2 & 123 & $6.04^{\mathrm{c}}$ \\
\hline N50 & $1.35^{\mathrm{b}}$ & 6.0 & 102 & 11.3 & 132 & $6.89^{\mathrm{b}}$ \\
\hline \multirow[t]{2}{*}{ N100 } & $1.74^{\mathrm{a}}$ & 6.1 & 113 & 12.4 & 132 & $8.28^{\mathrm{a}}$ \\
\hline & $* *$ & ns & ns & ns & ns & $* *$ \\
\hline
\end{tabular}

a-cThe values in each column followed by a different letter are significantly different at $\mathrm{P} \leq 0.05$ (Duncan). Significance of the F values: *, **Significant at the $\mathrm{P}<0.05$ and 0.01 , respectively; n.s., not significant. N0, 0 kg $\mathrm{N} \mathrm{ha}^{-1} ; \mathrm{N} 50,50 \mathrm{~kg} \mathrm{~N}^{-1}$; $\mathrm{N1} 100,100 \mathrm{~kg} \mathrm{~N} \mathrm{ha}^{-1}$.

Table 2. Effects of treatments (tillage and levels of $\mathrm{N}$ fertilisation) on crop performance at Site 2.

\begin{tabular}{|c|c|c|c|c|c|c|}
\hline & $\begin{array}{c}\text { Yield } \\
\left(\mathrm{t} \mathrm{ha^{-1 } )}\right.\end{array}$ & $\begin{array}{c}1000 \text { seeds weight } \\
\text { (g) }\end{array}$ & $\begin{array}{l}\text { Silique plant } \\
\text { (n) }\end{array}$ & $\begin{array}{l}\text { Seeds silique }{ }^{-1} \\
\text { (n) }\end{array}$ & $\begin{array}{l}\text { Plant height } \\
\text { (cm) }\end{array}$ & $\begin{array}{l}\text { Total biomass } \\
\qquad\left(\mathrm{t} \mathrm{ha} \mathrm{a}^{-1}\right)\end{array}$ \\
\hline \multicolumn{7}{|l|}{ Year } \\
\hline 2010-2011 & 2.05 & 5.1 & 104 & 12.1 & 139 & 4.16 \\
\hline \multirow[t]{2}{*}{ 2011-2012 } & 1.69 & 4.7 & 99.0 & 12.7 & 137 & 4.05 \\
\hline & $*$ & $*$ & $*$ & ns & ns & ns \\
\hline \multicolumn{7}{|l|}{ Tillage } \\
\hline CT & 1.68 & 4.7 & 101 & 12.4 & 136 & 3.76 \\
\hline \multirow[t]{2}{*}{ MT } & 2.06 & 5.1 & 102 & 12.4 & 140 & 4.46 \\
\hline & $*$ & $*$ & ns & ns & $*$ & $*$ \\
\hline \multicolumn{7}{|l|}{$\mathrm{N}$ level } \\
\hline NO & $1.34^{\mathrm{c}}$ & $4.3^{c}$ & $87.9^{c}$ & $11.8^{\mathrm{c}}$ & $125^{\mathrm{c}}$ & $2.89^{c}$ \\
\hline N50 & $1.83^{b}$ & $4.9^{\mathrm{b}}$ & $106^{\mathrm{b}}$ & $12.5^{\mathrm{b}}$ & $141^{b}$ & $4.18^{b}$ \\
\hline \multirow[t]{2}{*}{ N100 } & $2.44^{\mathrm{a}}$ & $5.5^{\mathrm{a}}$ & $110^{\mathrm{a}}$ & $13.0^{\mathrm{a}}$ & $148^{a}$ & $5.27^{\mathrm{a}}$ \\
\hline & $* *$ & $* *$ & $* *$ & $*$ & $* *$ & $* *$ \\
\hline Interactions & ns & ns & ns & ns & ns & ns \\
\hline
\end{tabular}

a-cWithin treatments, the values in each column followed by a different letter are significantly different at $\mathrm{P} \leq 0.05$ (Duncan). Significance of the $\mathrm{F}$ values: ${ }^{*},{ }^{* *},{ }^{* * *}$ Significant at the $\mathrm{P}<0.05$ and 0.01 , respectively; n.s., not significant. CT, conventional tillage; MT, minimum tillage; N0, $0 \mathrm{~kg} \mathrm{~N} \mathrm{ha}^{-1} ; \mathrm{N} 50,50 \mathrm{~kg} \mathrm{~N} \mathrm{ha}^{-1}$; $\mathrm{N1} 100,100 \mathrm{~kg} \mathrm{~N} \mathrm{ha}^{-1}$. 
$\mathrm{N} 120$, whereas this $\mathrm{N}$ dose determined seed silique $\mathrm{C}^{-1}$ comparable to N60 and significantly higher by $7.3 \%$ compared to N0. As regards to crop density factor, the highest yield was determined by $\mathrm{H}$ treatment, being higher by $56.4 \%$ than using $\mathrm{L}$ strategy, despite a reduced number of silique plant ${ }^{-1}$. In 2010-2011, in H plots, N60 treatment determined the highest oil content (33.7\%), whereas in L plots N120 determined an oil content (34.2\%) significantly higher than N60 (31.5\%) (Figure 3). In 2011-2012, the highest oil content (45.5\%) was determined by N0 in $\mathrm{L}$, whereas the lowest one was found for N0 in H. Moreover, with H density, N60 treatment determined a value (37.8\%) significantly higher both than $\mathrm{N} 0$ and $\mathrm{N} 120$, whereas with L density it produced the lowest value (35.7\%).

\section{Site 4}

The output of the analysis of variance revealed significant main effect of year for all parameters. Main effect of tillage was found only for yield, whereas main effect of fertiliser was found for yield and total biomass. No interactions between treatments were found (Table 4).

The best crop performance was detected in the first year, showing the highest values of all tested parameters. As regards to tillage treatments, CT determined yield and total biomass significantly higher than
MT by $43.6 \%$ and $20.7 \%$, respectively. Among fertiliser treatments, N100, MIX and SSW determined the highest yield values, whereas 100COMP and N0 showed the intermediate (and comparable to the previous three treatments) and the lowest results, respectively. A similar behaviour for N100, MIX and SSW was also observed for total biomass (but in this case with significant difference compared both to 100COMP and N0). SSW determined the highest absolute number of silique per plant, which was significantly higher by more than $100 \%$ than in N0, whereas the other fertilisers showed intermediate and comparable results among them. Finally, as for the plant height the N100 showed the highest absolute value, being statistically higher by $11 \%$ than in N0, but comparable to the other treatments.

Figure 4 reports seed oil content for each year of study, divided by $\mathrm{N}$ fertilisers, for each tillage strategy. In the first crop cycle, the CT strategy determined the highest absolute value combined with 100COMP (37.9\%). The MT strategy determined higher oil content with N100 (37.7\%) and SSW (38.2\%), whereas 100COMP treatment showed the lowest in absolute value. In 2011-2012, in CT plots the highest oil content was found for MIX (43.9\%) and the lowest one for SSW (41.4\%), whereas in MT the highest value was determined by SSW (43.7\%) and the lowest by N100 in absolute value (38.1\%).

Table 3. Effects of treatments ( $\mathrm{N}$ fertilisation levels and sowing density) on crop performance at Site 3.

\begin{tabular}{|c|c|c|c|c|c|}
\hline & $\begin{array}{l}\text { Yield } \\
\left(\mathrm{t} \mathrm{ha}^{-1}\right)\end{array}$ & $\begin{array}{l}1000 \text { seeds weight } \\
(\mathrm{g})\end{array}$ & $\begin{array}{l}\text { Silique plant } \\
\text { (n) }\end{array}$ & $\begin{array}{l}\text { Seeds silique }{ }^{-1} \\
\text { (n) }\end{array}$ & $\begin{array}{l}\text { Plant height } \\
\qquad(\mathrm{cm})\end{array}$ \\
\hline \multicolumn{6}{|l|}{ Year } \\
\hline 2010-2011 & $1.39^{b}$ & 4.9 & $32.3^{b}$ & 14.3 & $148^{a}$ \\
\hline \multirow[t]{2}{*}{ 2011-2012 } & $1.64^{\mathrm{a}}$ & 5.0 & $36.1^{\mathrm{a}}$ & 14.2 & $133^{b}$ \\
\hline & $* *$ & ns & $* *$ & $\mathrm{~ns}$ & $* * *$ \\
\hline \multicolumn{6}{|l|}{ N level } \\
\hline No & $1.11^{\mathrm{c}}$ & $4.8^{b}$ & $29.3^{c}$ & $13.7^{\mathrm{b}}$ & $130^{c}$ \\
\hline $\mathrm{N} 60$ & $1.54^{\mathrm{b}}$ & $5.1^{\mathrm{a}}$ & $34.4^{\mathrm{b}}$ & $14.8^{\mathrm{a}}$ & $145^{b}$ \\
\hline \multirow[t]{2}{*}{ N120 } & $1.82^{\mathrm{a}}$ & $4.9^{\mathrm{b}}$ & $38.1^{\mathrm{a}}$ & $14.7^{\mathrm{a}}$ & $152^{\mathrm{a}}$ \\
\hline & $* * *$ & $*$ & $* * *$ & $*$ & $* * *$ \\
\hline \multicolumn{6}{|l|}{ Sowing density } \\
\hline $\mathrm{L}$ & $1.17^{\mathrm{b}}$ & 5.0 & $39.4^{\mathrm{a}}$ & 14.8 & 141 \\
\hline \multirow[t]{2}{*}{$\mathrm{H}$} & $1.83^{\mathrm{a}}$ & 4.9 & $28.5^{b}$ & 14.1 & 144 \\
\hline & $* * *$ & ns & $* * *$ & ns & ns \\
\hline Interactions & ns & ns & ns & ns & ns \\
\hline
\end{tabular}

${ }^{\text {a-c }}$ Within treatments, the values in each column followed by a different letter are significantly different at $\mathrm{P} \leq 0.05$ (Duncan). Significance of the $\mathrm{F}$ values: ${ }^{*}, * *, * * *$ Significant at the $\mathrm{P}<0.05,0.01$ and 0.001 , respective-

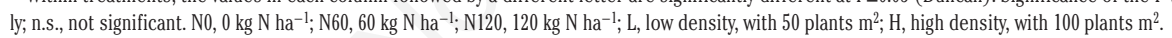

A

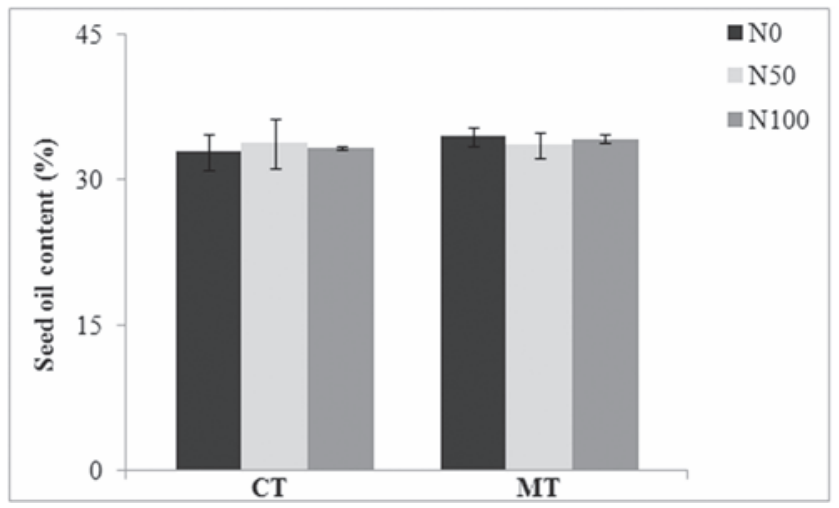

$\mathrm{B}$

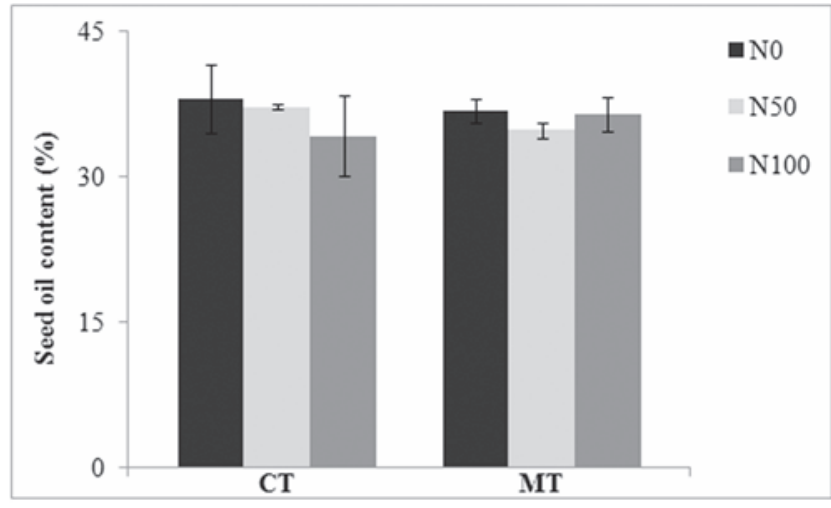

Figure 2. Seed oil content (\%) in Site 2 in (A) 2010-2011 and (B) 2011-2012, divided by nitrogen (N) fertiliser level for each tillage strategy. Reported values are mean \pm standard deviation. 
Table 4 Effects of treatments (tillage and fertilisers) on crop performance at Site 4.

\begin{tabular}{|c|c|c|c|c|c|}
\hline & 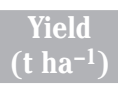 & $\begin{array}{l}1000 \text { seeds weight } \\
(\mathrm{g})\end{array}$ & $\begin{array}{l}\text { Silique plant } \\
\text { (n) }\end{array}$ & $\begin{array}{l}\text { Plant height } \\
\text { (n) }\end{array}$ & $\begin{array}{l}\text { Total biomass } \\
\qquad(\mathrm{t} \mathrm{ha}-1)\end{array}$ \\
\hline \multicolumn{6}{|l|}{ Year } \\
\hline 2010-2011 & $2.40^{\mathrm{a}}$ & $4.6^{\mathrm{a}}$ & $230^{\mathrm{a}}$ & $155^{\mathrm{a}}$ & $10.60^{\mathrm{a}}$ \\
\hline \multirow{2}{*}{ 2011-2012 } & $0.84^{\mathrm{b}}$ & $3.8^{\mathrm{b}}$ & $87^{b}$ & $137^{b}$ & $6.61^{\mathrm{b}}$ \\
\hline & $* * *$ & $* * *$ & $* * *$ & $* * *$ & $* * *$ \\
\hline \multicolumn{6}{|l|}{ Tillage } \\
\hline CT & $1.91^{\mathrm{a}}$ & 4.2 & 172 & 148 & $9.41^{\mathrm{a}}$ \\
\hline \multirow{2}{*}{ MT } & $1.33^{\mathrm{b}}$ & 4.3 & 145 & 144 & $7.79^{\mathrm{b}}$ \\
\hline & $*$ & ns & ns & ns & ns \\
\hline \multicolumn{6}{|l|}{ Fertilisers } \\
\hline N100 & $1.84^{\mathrm{a}}$ & 4.2 & $180^{\mathrm{ab}}$ & $151^{\mathrm{a}}$ & $9.25^{\mathrm{a}}$ \\
\hline 100COMP & $1.48^{\mathrm{ab}}$ & 4.4 & $156^{\mathrm{ab}}$ & $147^{\mathrm{ab}}$ & $7.56^{\mathrm{b}}$ \\
\hline MIX & $1.74^{\mathrm{a}}$ & 4.2 & $160^{\mathrm{ab}}$ & $146^{\mathrm{ab}}$ & $9.33^{\mathrm{a}}$ \\
\hline SSW & $1.85^{\mathrm{a}}$ & 4.3 & $201^{\mathrm{a}}$ & $148^{a b}$ & $9.94^{\mathrm{a}}$ \\
\hline \multirow[t]{2}{*}{ No } & $1.18^{b}$ & 4.2 & $97^{\mathrm{b}}$ & $136^{\mathrm{b}}$ & $6.90^{\mathrm{b}}$ \\
\hline & $*$ & ns & ns & $\mathrm{ns}$ & $* * *$ \\
\hline Interactions & ns & ns & ns & ns & ns \\
\hline
\end{tabular}

a-c Within treatments, the values in each column followed by a different letter are significantly different at $\mathrm{P} \leq 0.05$ (Duncan). Significance of the $\mathrm{F}$ values: ${ }^{*},{ }^{* *},{ }^{* * *}$ Significant at the $\mathrm{P}<0.05$ and 0.001 , respectively; n.s., non significant. CT, conventional tillage; MT, minimum tillage; N100, mineral N fertiliser at $100 \mathrm{~kg} \mathrm{~N}^{-1}$; $100 \mathrm{COMP}$, compost at $100 \mathrm{~kg}^{\mathrm{N}} \mathrm{ha}^{-1}$; MIX, compost mixed with mineral N fertiliser; SSW, sewage sludge from urban wastewater; N0, unfertilised control.

A

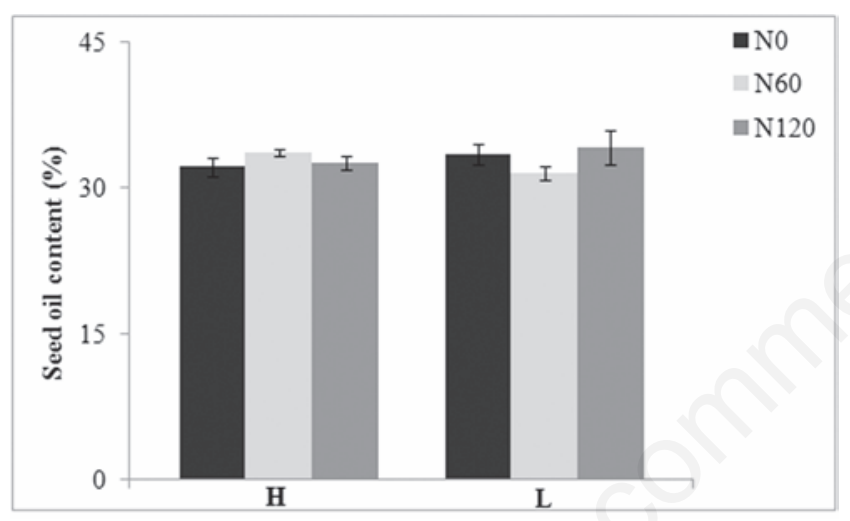

B

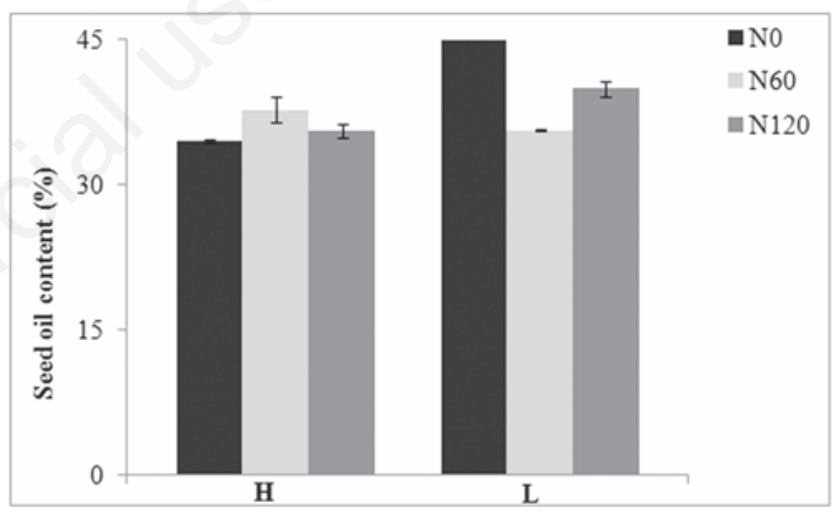

Figure 3. Seed oil content (\%) in Site 3 in (A) 2010-2011 and (B) 2011-2012, divided by nitrogen (N) fertiliser level for each sowing strategy. Reported values are mean \pm standard deviation.

A

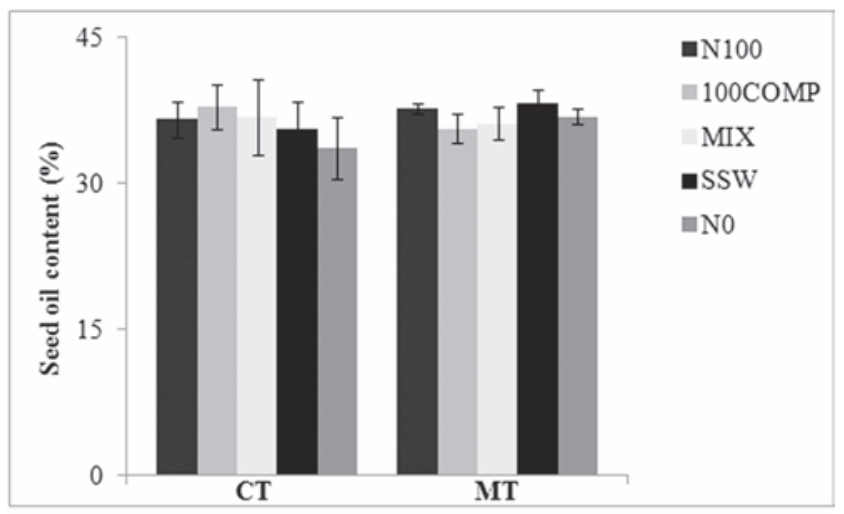

B

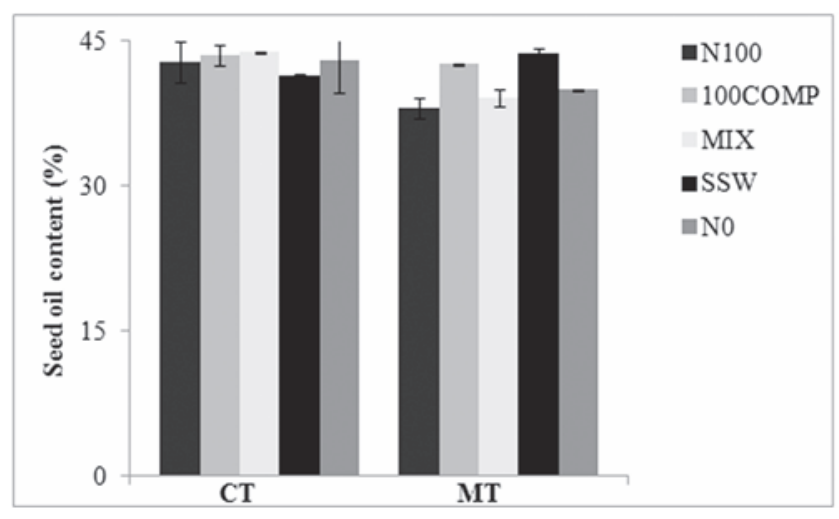

Figure 4. Seed oil content (\%) in Site 4 in (A) 2010-2011 and (B) 2011-2012, divided by nitrogen (N) fertilisers for each tillage strategy. Reported values are mean \pm standard deviation. 


\section{Discussion}

In Site 1, the crop showed a good adaptability to this semi-marginal area and the highest nitrogen fertilisation (N100) positively influenced the yield, irrespective of the seasonal differences in the weather parameters. This $\mathrm{N}$ rate falls within the range indicated by Gan et al. (2007) who has shown that the amount of $\mathrm{N}$ fertiliser required for seed yields to plateau in various Brassica species ranged from about 100 to $160 \mathrm{~kg} \mathrm{~N} \mathrm{ha}^{-1}$, with the highest values reported for $B$. juncea. By contrast, other studies indicated that a rate was not identified in which $B$. carinata yields were maximised (Johnson et al., 2013). As regards to seed oil obtained for biodiesel potential production, in the first year (more rainy than the long-term period and milder than the second year) the $\mathrm{N}$ fertilisation positively influenced seed oil content. The oil content values were comparable with those observed in other studies for the same crop (Kaur and Sidhu, 2004; Johnson et al., 2013).

Among the four study sites, the best yield results were obtained by MT and N100 treatments in the Site 2. To define sustainable bioenergy chain, as well as to reduce the use of energy during the crop cultivation phase, it is fundamental the application of low external input cultivation systems. The tillage strategies in Site 2 were comparable between them, similarly to another study that found as the reduction of mechanical operations did not negatively influence $B$. carinata production and seed oil content (Lazzeri et al., 2009). This result would confirm the possibility of reducing production costs and environmental impacts for this crop. Despite the notable variability in weather conditions between the two trial years, it did not cause significant differences for half of tested parameters (seeds silique ${ }^{-1}$, plant height and total biomass) in this site. Again, the N100 dose produced the best crop yield and oil production, confirming findings of Pramanik et al. (1996) who noted that the growth, seed and oil yields of the crop significantly improved with increasing $\mathrm{N}$ rates up to $100 \mathrm{~kg} \mathrm{~N} \mathrm{ha}^{-1}$, in different environmental conditions.

In Site 3, the most favourable weather conditions in the second year determined the highest production, which increased with the $\mathrm{N}$ level. This positive yield response to $\mathrm{N}$ rates was also reported by other authors for this crop in different environment (Kaur and Sidhu, 2004). Moreover, the best yield performance was found applying the high-density strategy, which likely hastens maturity and reduces the risk of crop failure. By contrast, Pan et al. (2012) reported that the maximum seed yield was produced in a wide range of plant population from 34 plants $\mathrm{m}^{-2}$ to 114 plants $\mathrm{m}^{-2}$. As regards to seed oil percentage, in both years the $\mathrm{N} 60$ level reached the highest values with $\mathrm{H}$ strategy. Conversely, N120 determined better results with $\mathrm{L}$ than with $\mathrm{H}$ strategy. These outcomes would suggest that with high density of sowing it is possible/necessary to reduce the $\mathrm{N}$ fertilisation to obtain good results for oil. Finally, the obtained findings in Site 4 indicate the possibility to recycle, for $B$. carinata cultivation, both municipal solid waste and sewage sludge of urban wastewater, which are wastes so abundant in Mediterranean regions. These wastes present notable contents of organic matter and substantial quantities of nutrients, whereas main potential toxic elements (heavy metals) could be lower than the maximum permissible limits for land application fixed by current legislation, as in the organic materials used in our study. Therefore, their use in agriculture can contribute to closing the natural ecological cycles, without adversely affecting the environment (Diacono and Montemurro, 2011). In particular, MIX and SSW treatments determined productive results comparable to those obtained with mineral fertiliser. Therefore, organic fertilisers could (partially or completely) substitute the mineral fertiliser, in accordance to Montemurro et al. (2006) findings on other crops. In MT plots, the SSW also determined the highest oil content of seeds, whereas in CT there was more variability between years in the fertiliser effect on this parameter. This last result indicates (as in Site 1) that the agronomic management did not overcome the limit imposed by the genetic control of oil content parameter, as it was found also in other crops (Montemurro and De Giorgio, 2005). More specifically, this would confirm Zanetti et al. (2009) findings on B. carinata, indicating that the level of production inputs did not modify oil percentage, thus suggesting that this trait is more closely related to variety and to year. By contrast, Torabi et al. (2008) found that the tillage method significantly affected $B$. napus L. yield and oil content.

\section{Conclusions}

Information on proper agronomic strategies for energy crops is necessary to optimise their production, thus offering new perspectives to diversify farming activities and also cultivate marginal areas.

$B$. carinata is an oil-bearing crop that is characterised by rusticity and adaptability to different environmental conditions. In our study, among the tested agronomic practices, the positive influence on the crop productive results of high $\mathrm{N}$ fertilisation, high density of sowing, and organic fertilisers application was detected. In particular, it was showed that the reduction of mechanical operations did not negatively influence $B$. carinata production and seed oil content. Our results also suggest that with high density of sowing it is possible to reduce the $\mathrm{N}$ fertilisation, to obtain positive oil yield response. Therefore, considering seed yield and oil content, $B$. carinata could have a potential for biodiesel production in the study sites.

On the whole, in the four Mediterranean study sites of this research, the crop seemed to be self-adapted to specific agro-pedo-climatic conditions of each site, thus avoiding competition for land and resources with food crops in not-marginal areas. However, the main perspectives of the research regard the evaluation of the environmental impact of cultivation in other different marginal areas and alternative cropping systems.

\section{References}

Cardone M, Mazzoncini M, Menini S, Rocco V, Senatore A, Seggiani M, Vitolo S, 2003. Brassica carinata as an alternative oil crop for the production of biodiesel in Italy: agronomic evaluation, fuel production by transesterification and characterization. Biomass Bioenerg. 25:623-36.

Cosentino SL, Copani V, Patanè C, Mantineo M, D’Agosta GM, 2008. Agronomic, energetic and environmental aspects of biomass energy crops suitable for Italian environments. Ital. J. Agron. / Riv. Agron. 2:81-95.

Del Gatto A, Melilli MG, Raccuia SA, Pieri S, Mangoni L, Pacifico D, Signor M, Duca D, Foppa Pedretti E, Mengarelli C, 2015. A comparative study of oilseed crops (Brassica napus L. subsp. oleifera and Brassica carinata A. Braun) in the biodiesel production chain and their adaptability to different Italian areas. Ind. Crops Prod. 75:98-107.

Diacono M, Montemurro F, 2011. Long-term effects of organic amendments on soil fertility. In: E. Lichtfouse, M. Hamelin, M. Navarrete, P. Debaeke (Eds.), Sustainable agriculture. Springer, Amsterdam, the Netherlands, 2:761-786.

Duca D, Toscano G, Riva G, Mengarelli C, Rossini G, Pizzi A, Del Gatto A, Foppa Pedretti E, 2015. Quality of residues of the biodiesel chain in the energy field. Ind. Crops Prod. 75:91-7.

European Commission, 1986. Council Directive 86/278/EEC of 12 June 1986 on the protection of the environment, and in particular of the 
soil, when sewage sludge is used in agriculture. In: Official Journal, L 181, 04/07/1986, pp 6-12.

European Environment Agency (EEA), 2007. Estimating the environmentally compatible bioenergy potential from agriculture. Report no. 12/2007. EEA, Copenhagen, Denmark.

Fischer G, Prieler S, Van Velthuizen H, Berndes G, Faaij A, Londo M, De Wit M, 2010. Biofuel production potentials in Europe: sustainable use of cultivated land and pastures, Part II: land use scenarios. Biomass Bioenerg. 34:173-87.

Gan Y, Malhi SS, Brandt S, Katepa-Mupondwa F, Kutcher HR, 2007. Brassica juncea canola in the Northern Great Plains: Responses to diverse environments and nitrogen fertilization. Agron. J. 99:1208-18.

Italian Regulation, 2010. Decreto Legislativo 29 aprile 2010, n.75. Riordino e revisione della disciplina in materia di fertilizzanti, a norma dell'articolo 13 della legge 7 luglio 2009, n. 88. In: G.U. n. 121, 26/05/2010.

Johnson EN, Malhi SS, Hall LM, Phelps S, 2013. Effects of nitrogen fertilizer application on seed yield, $\mathrm{N}$ uptake, $\mathrm{N}$ use efficiency, and seed quality of Brassica carinata. Can. J. Plant Sci. 93:1073-81.

Kaur P, Sidhu MS, 2004. Effect of sowing date, nitrogen level and row spacing on the growth and yield of African sarson (Brassica carinata A. Braun). J. Res. Punjab Agric. Univ. 41:27-34.

Lazzeri L, D’Avino L, Mazzoncini M, Antichi D, Mosca G, Zanetti F, Del Gatto A, Pieri S, De Mastro G, Grassano N, Cosentino S, Copani V, Ledda L, Farci R, Bezzi G, Lazzari A, Dainelli R, Spugnoli P, 2009. On farm agronomic and first environmental evaluation of oil crops for sustainable bioenergy chains. Ital. J. Agron. 4:171-80.

Montemurro F, De Giorgio D, 2005. Quality and nitrogen use efficiency of sunflower grown at different nitrogen levels under
Mediterranean conditions. J. Plant Nutr. 28:335-50.

Montemurro F, Maiorana M, Ferri D, Convertini G, 2006. Nitrogen indicators, uptake and utilization efficiency in a maize and barley rotation cropped at different levels and sources of $\mathrm{N}$ fertilization. Field Crop Res. 99:114-24.

Pan X, Caldwell CD, Falk KC, Lada R, 2012. The effect of cultivar, seeding rate and applied nitrogen on Brassica carinata seed yield and quality in contrasting environments. Can. J. Plant Sci. 92:961-71.

Pramanik SC, Singh NP, Singh S, Garnayak LM, 1996. Irrigation and nitrogen effects on oil yield and nitrogen uptake by Ethiopian mustard (Brassica carinata). Indian J. Agron. 41:101-7.

Soil Survey Staff, 1999. Soil taxonomy. A basic system of soil classification for making and interpreting soil surveys. Agriculture Handbook 436. USDA-NRCS, Washington, DC, USA.

Stamigna C, Chiaretti D, Chiaretti E, Prosini PP, 2012. Oil and furfural recovery from Brassica carinata. Biomass Bioenerg. 39:478-83.

Torabi H, Naghdibadi HA, Omidi H, Amirshekari H, Miransari M, 2008. Effects of soil tillage, canola (Brassica napus L.) cultivars and planting date on canola yield, and oil and some biological and physical properties of soil. Arch. Agron. Soil Sci. 54:175-88.

UNESCO-FAO, 1963. Bioclimatic map of the Mediterranean zone; NS162/II, 22A. UNESC0, Paris - FA0, Rome.

Zanetti F, Vamerali T, Mosca G, 2009. Yield and oil variability in modern varieties of high-erucic winter oilseed rape (Brassica napus L. var. oleifera) and Ethiopian mustard (Brassica carinata A. Braun) under reduced agricultural inputs. Ind. Crop. Prod. 30:265-70.

Zegada-Lizarazu W, Elbersen HW, Cosentino SL, Zatta A, Alexopoulou E, Monti A, 2010. Agronomic aspects of future energy crops in Europe. Biofuel. Bioprod. Bioref. 4:674-91. 